\title{
SUCCESSION AND THE DEVELOPMENT OF ALLUVIAL COMMUNITIES AFTER A FLOOD IN 1997
}

\author{
LUCIE GROHMANOVÁ
}

\begin{abstract}
Mendel University in Brno, Faculty of Forestry and Wood Technology, Department of Forest Botany, Dendrology and Geobiocoenology, Zemědělská 3, 613 00, Brno, Czech Republic, e-mail: xgrohman@mendelu.cz
\end{abstract}

Received: $19^{\text {th }}$ December 2011, Accepted: $8^{\text {th }}$ June 2012

\begin{abstract}
This paper details a ten-year period in the development of floodplain biotopes after a disastrous flood in 1997 at three sites on along the Spojená Bečva River in the Zlín and Olomouc regions, Czech Republic. Two of the sites are located on gravel bars, whilst the third site is located on a bank characterized as bare bed flysch sediments uncovered after a flood in 1997. After the flood, the previously homogeneous alluvial environment changed into a varied mosaic of biotopes with renewed conditions for the development of willows (Saliceta fragilis inferiora) and stands of Ulmi-fraxineta carpini superiora and Alni glutinosae-saliceta superior. A detailed study of the vegetation at the selected sites was conducted annually from 1998-2002, and in 2008, using $10 \mathrm{~m}$ wide transects oriented perpendicular to the river. The obtained data, including phytocoenological records, were compared with the vegetation communities ten years earlier and during the examined time interval. The dependence of particular types of biotopes on site conditions was described.

In total, we identified and located 14 types of biotopes, completed 58 relevés, and found 245 species. The results show that succession is faster at moist sites with fine sediment in Rybáře and slower at drier sites without fine sediment in Lhotka nad Bečvou and Choryně. The flooding of the floodplain forest was not destructive for most species outside the flood channel. Between 2004 and 2006, short-lived and segetal species retreated. The dominant species are Phalaris arundinacea, Urtica dioica, Echium vulgare, and Artemisia vulgaris. Invasive neophytes included Reynoutria japonica, Solidago canadensis, Impatiens glandulifera and Robinia pseudoacacia.

The results obtained through this project can serve as a valuable foundation for decisions regarding nature conservation.

Keywords: flood, Bečva River, dynamic fluvial succession, alluvial plant communities, river bed, gravel bar
\end{abstract}

\section{INTRODUCTION}

The riparian landscape of a meandering river system is a heterogeneous land mosaic that can change rapidly through time in response to fluvial geomorphologic factors (Gregory et al., 1991; Malanson, 1993; Bayley, 1995; Steiger et al., 2005). Alluvial plains are highly dynamic components of the landscape, as demonstrated by, geological, geomorphologic 
and palaeobotanical studies (Buček et al., 1998). Today, the character of alluvial plains in the Czech Republic is often very different from their original structure (Maděra et al., 2011).

The fluvial landscape along the Spojená Bečva River has been formed by regular spring and summer floods that provide floodplain forests with necessary moisture. In previous centuries, floods in the Bečva River were quite frequent, as is clear from the list of years of floods for the last three centuries: June 21, 1883; July 20-24, 1891; April 1900; May 1911; June 1926; July 7-12, 1997; June 24-25, 2009; and May 17-18 2010 (http://uprm.sweb.cz/krajina).

Floods are a significant factor in the formation of alluvial plains and their associated vegetation. A sufficient amount of moisture after floods or during elevated water levels, together with muddy sediments, provides the vegetation of alluvial streams with the necessary nutrients during the year. Alluvial communities, together with floodplains, are parts of extraordinarily productive biotopes. The main factors influencing the species diversity of the vegetation in these communities include the dynamics of the water currents and their history; geographic factors; alluvial-plain morphology; flood frequency, timing and duration; community dominants and the disappearance of large mammals (Maděra et al., 2009).

In addition to natural influences, the alluvial landscape has been strongly affected by human activities associated with cultivation and the agricultural use of parts of the fluvial landscape as well as construction. As a consequence, the soil properties, groundwater levels, and the structure and composition of adjacent riparian stands, as well as the river vegetation and related animal species, changed. Human activities have included the felling of forests, wastewater discharge, the building of dams, the straightening of rivers and their regulation, and other factors, considerably affecting the dynamics of fluvial biotope succession (Wenger et al., 1990).

The dynamic fluvial succession of alluvial biotopes is understood to encompass a range of aquatic, wetland, terrestrial, natural or human-affected ecosystems maintained by fluvial processes (Buček, Lacina 1994). Large floods are thus a natural part of the homeorhetic dynamics of the landscape of alluvial plains (Buček, 2010).

Some highly valued sections were preserved on the Bečva river where succession is monitored, and must be maintained in the future to continue site protection. Important biotopes may exist but are mostly remnants of a former dynamic system (Ward et al., 2002). In addition, on the Bečva River, some highly valuable sections have been preserved where succession can be observed; it would be strongly advisable to preserve these for the future and to include them in nature conservation measures. Six sites regularly modified by floods in preserved sections of the original river bed support a highly varied mosaic of biotopes: Bečva pod Osekem, Bečva u Familie, Hrubý závrtek, Ústí Milotického potoka, Bečva pod Choryní and Bečva u Lhotky (Pod Břehy) (Lacina et al., 1998).

The aim of the paper is to describe and evaluate vegetation at selected sites along the Bečva River after the disastrous flood of 1997. The obtained data can enable a better understanding of the dynamic processes in an alluvial plain and, at the same time, support the protection of sites within the EU programme "Natura 2000". 


\section{MATERIALS AND METHODS}

\section{Study area}

The study area is located in a part of the Spojená Bečva River between the municipalities of Lhotka nad Bečvou and Jezernice in the Zlín and Olomouc regions, districts of Vsetín and Přrerov, Czech Republic.

The selected sites are as follows:

Lhotka nad Bečvou, "Pod Břehy" - site L

Choryně, "Vyústění potoka Mřenky" - site M

Rybáře u Drahotuš, "Rybáře" - site R

Fig. 1: Map depicting the study area in central Moravia (Czech Republic)

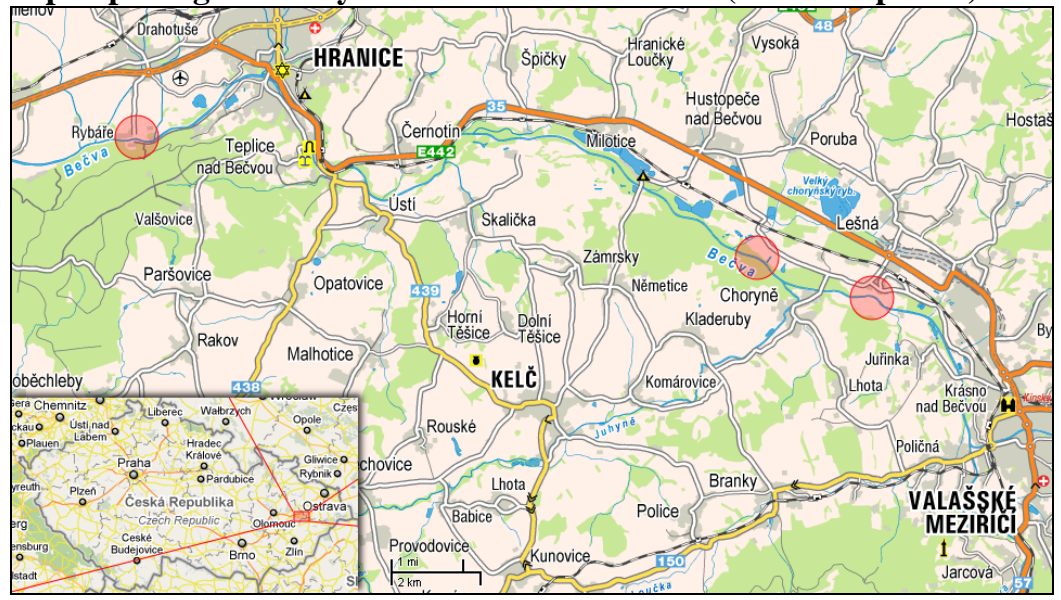

source: cykloserver.cz, maps.google.cz

Geomorphologically, the area falls within the Carpathian province, Western Carpathian subprovince (Demek, 1987). Biogeographically, the area is in the Hranice bioregion (Culek, 1996).

The Loess Plain in the river bed of the Bečva consists of flood sediments (Holocene), loess (Upper Pleistocene), gravel sands (Upper Pleistocene) and calcareous loam (Lower Badenian). The predominant part of the flat area in the Bečva gate is formed by fluvial, deluvial and eolic sediments. The oldest fluvial sediments are remnants of Lower Pleistocene gravel. For example, in Jezernice, near Rybáře, there are loess sediments (terrain surface 275-295 m a. s. 1. and 250-270 m a. s. 1.). By Drahotuše, on the left bank, the main terrace (Radslavická terasa) has evolved with a total sediment thickness of up to $15 \mathrm{~m}$. On the right riverbank, the gravel at the valley bottom is covered by up to $9 \mathrm{~m}$ of loess (Pleistocene) (Czudek, 1997).

A 10m wide river profile was selected perpendicularly to the Bečva River at each of the study sites (sites L, M and R). The transects of these sites were chosen to survey biotopes and their successional development. Therefore, these sites were chosen at formerly established permanent monitoring sites to allow comparison with previous years (Lacina, 2003, 2007; Klečka, 2004a; Lacina et al., 1998). As a result, we were able to use data available from the years 1998-2002 (inclusive) and 2008. 
These transects were at permanent monitoring plots divided into sections - biotopes from the Bečva River currently perpendicular to the bank scour. The individual types of biotopes are described referencing the ecological and physical site conditions and presented in the scheme below (Fig. 2).

\section{Fig. 2: The scheme of the individual transects of area of interest}

(the scheme was drawn upstream, individual types of biotopes are marked by Arabic numerals, with indices in rectangles; the numbers of phytocoenological records are stated in circles)
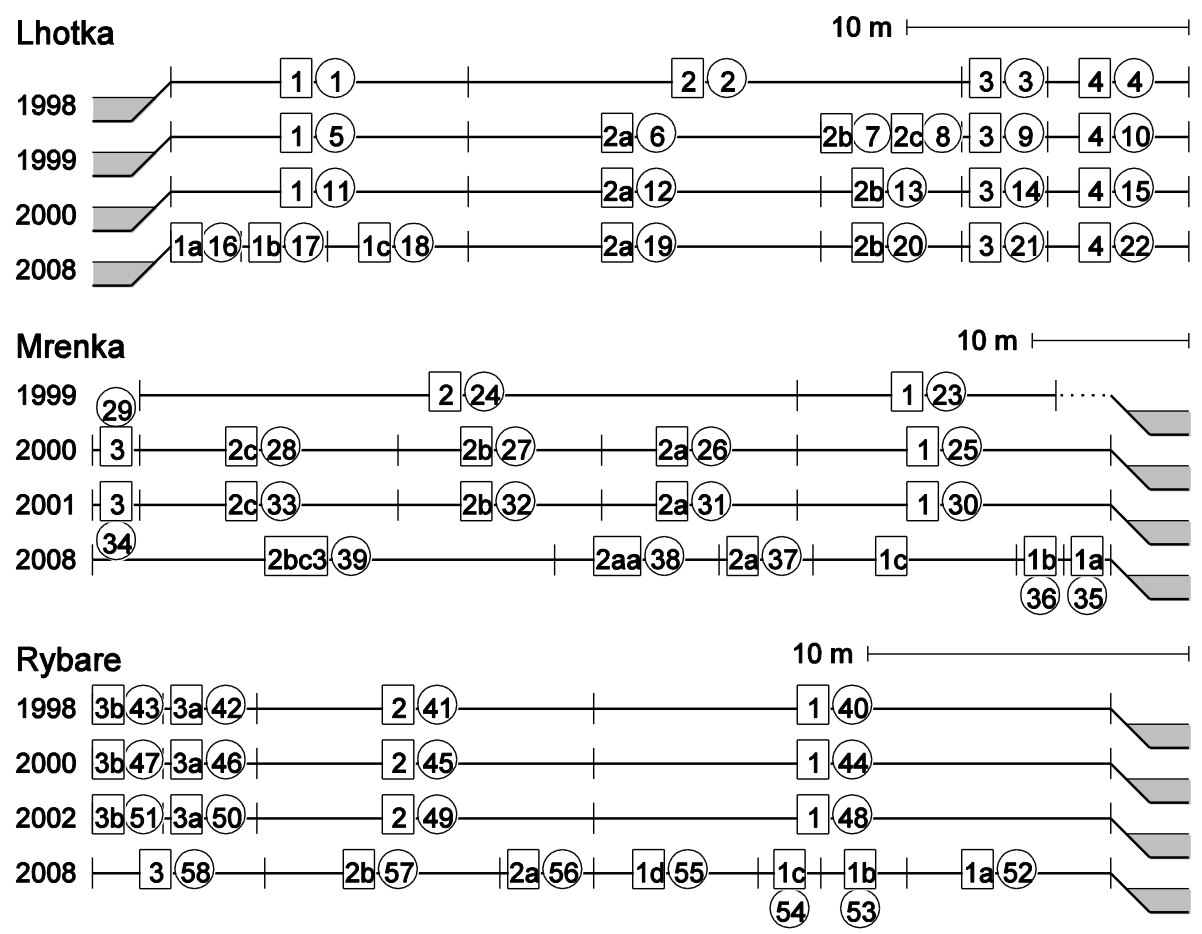

The following is an outline of the biotopes:

1) gravel bar overgrown by herb and woody vegetation

1a) gravel part of the bed with grass vegetation, predominantly Phalaris arundinacea

1b) pebble part of flood bed covered in fine sediments, overgrown by stands of willows

1c) rock-gravel part of the bed with fine sediments, herb vegetation

1d) gravel part of the bed with fine sediments overgrown with woody vegetation (willows)

2) bottom of an occasional lagoon overgrown with herb and woody vegetation

2a) gravel part of the bed covered in fine sediment with herb vegetation (predominantly Urtica dioica)

2aa) herb vegetation with an admixture of woody species on the fine sandy part of the bed

2b) gravel part of the bed with fine sediments overgrown with woody vegetation (willows)

$2 \mathrm{bc} 3$ ) open herb vegetation on gravel - sand fluvial sediment

3) right-bank scour overgrown with herb vegetation (barrens)

3a) gradually collapsing right-bank scour overgrown with herb vegetation

3b) flat part of the bed over the right-bank scour overgrown with herb vegetation (barrens)

4) gradually collapsing bank scour overgrown with herb vegetation

note: biotope 2 at the Lhotka and Mřenka sites corresponds with the biotope name 2aa; biotope 1 in Rybáře is rocky. The Lhotka site is not only a gravel bar, but it is partly a bare bed of flysch sediments. 


\section{The recording and processing of the phytocoenological data}

For the evaluation of the alluvial biocoenoses the geobiocoenological method of the data's collection was chosen - published by Ambros (2003). The herb layer was described using phytocoenological relevés in particular biotopes bound to the transect width. These phytocoenological relevés were placed along the transect in the central part of each biotype. In total, 58 phytocoenological relevés were recorded and evaluated. The abundance/dominance scale (Braun-Blanquet) was used for the evaluation of the cover of the herb layer. The synusia of woody species was described with a focus on species composition, layers and cover (Zlatník et al., 1976). The relevés were also used as data for the establishment of geobiocoenological units (groups of geobiocoen types - GGT). On the gravel bars of the flood channel Saliceta fragilis inferiora 3B-C 5a predominate, and the lowest permanently waterlogged parts of the channel are dominated by GGT Alni glutinosae-saliceta superiora $2 \mathrm{BC} 5 \mathrm{~b}$.

The phytocoenological relevés were edited in the database application TURBOVEG for Windows (Hennekens, Schaminée, 2001). The JUICE 7.0 application (Tichý, 2002) was the main tool used for the analysis of the phytocoenological data, including calculation of fidelity and a diversity index (Dufręne \& Legendre, 1997). Ellenberg's indicator values (Ellenberg, 1996) and the frequency and fidelity of species were calculated, and synoptic tables were created. The differences in vegetation composition were evaluated based on the synoptic tables with calculations of the frequency, fidelity and mean (non-zero) cover. The relationship of a species to its environment was evaluated based on its ecological properties (Ambros, Štykar 1999; Ellenberg, 1996) as well as the species' population strategies (Grime, 1979; Tichý, 2002). The Kruskal-Wallis test (non-parametric alternative to ANOVA) was used to evaluate the effect of the biotope on the number of species. The relation of the age of the biotope (number of years from the flood in 1997) with selected variables (Shannon-Wiener diversity index, Simpson index, number of herbs, Ellenberg indicator values and CSR-strategies) was ascertained using Spearman non-parametric correlations. Correlation coefficients were calculated for each biotope separately. For biotope 4 we only had data from site L for 1998-2000 and 2008, therefore, we did not calculate the correlation coefficients for this biotope. Statistical analyses were performed in Statistica 10 (StatSoft, Oklahoma, USA) and R 2.9.0 (The R Foundation for Statistical Computing, 2009).

For a statistical evaluation of phytocoenological relevés with separate characteristics we selected basic biotopes referred to as biotope 1, 2, 3, and 4 (without a more detailed division into subgroups) for simplification and better clarity. Using the Shannon - Wiener diversity index (Hill, 1973) we evaluated differences in species diversity of plants in the selected transects.

Ecological groups of species by biotope were classified using the catalogue of biotopes in the Czech Republic (Katalog biotopů České republiky) (Chytrý et al., 2010), and their proportions in phytocoenological relevés were analysed using Microsoft Office (Excel). A list of ecological groups of species was created to differentiate opportunistic species from indigenous (site-original, floodplain or alluvial, and site-unoriginal) species within the succession in (chosen transects) gravel bars of the flood channel. For forest species, we also considered the vegetation layer distribution (Zlatník, 1970); for non-forest species we considered classification in biotopes (Chytrý, Kučera, Kočí, eds. 2001).

The sources for maps are the Internet websites cykloserver.cz (detail) and maps.google.cz (Czech Republic). The data were further processed into the final form using Inkscape and Gimp. 


\section{RESULTS}

The overview of the types of biotopes and sites dependent upon the number of relevés and the total number of species is presented in tab. 1. Regarding the species diversity, site $\mathrm{L}$ is the richest (160 species). The lowest number of species was found at site $\mathrm{R}$ (138 species), which is more advanced in succession. With regard to the total number of species, the richest biotope is biotope 2, which is well supplied with water and is not disturbed as often as biotope 1 , which is located close to the river.

Table 1: The types of biotopes and sites dependent upon on the number of relevés and the total number of species

\begin{tabular}{|l|c|c|c|}
\hline & $\begin{array}{c}\text { number of } \\
\text { relevés }\end{array}$ & $\begin{array}{c}\text { total number of } \\
\text { species }\end{array}$ & $\begin{array}{c}\text { mean number of } \\
\text { species }\end{array}$ \\
\hline biotope 1 & 19 & 125 & 19 \\
\hline biotope 2 & 22 & 186 & 29 \\
\hline biotope 3 & 13 & 142 & 23 \\
\hline biotope 4 & 4 & 49 & 17 \\
\hline site $\boldsymbol{L}$ & 22 & 160 & 24 \\
\hline site $\boldsymbol{M}$ & 17 & 149 & 26 \\
\hline site $\boldsymbol{R}$ & 19 & 138 & 21 \\
\hline
\end{tabular}

Fig. 3 and 4 show the box graphs for the number of species by biotopes and by individual years. Table 4 and fig. 3 show that the number of species is significantly influenced by the types of the biotopes (Kruskal-Wallis chi-squared $=9.36, \mathrm{df}=3$, p-value $=0.025$ ). Biotope 2 has the most plant species, then the number gradually decreases in biotopes 3 and 4 . Biotopes 2 to 4 have approximately the same variability as regards the number of species which differentiates them from biotope 1 , where the variability of the number of species is higher (phytocoenological relevés capture from several up to about 50 species). The mean value of the number of species is the lowest in biotope 1. This result also follows from the disturbance effect, which is the most obvious near the pulsing water level of the river (biotope 1).

Fig. 3: The median number of species in individual biotopes

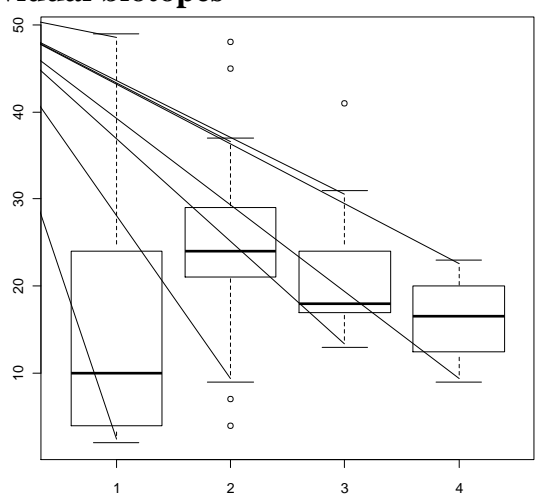

Fig. 4: The median number of species in individual years

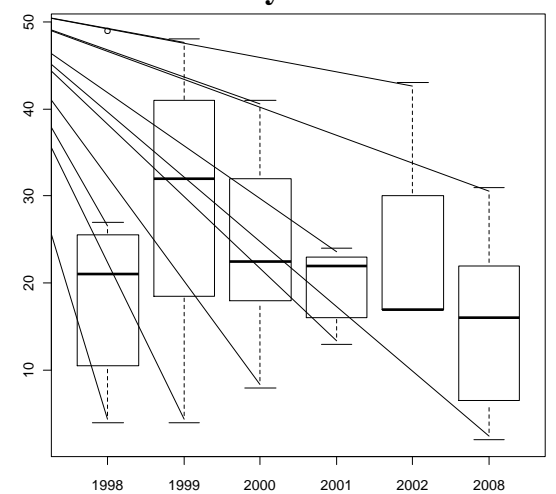

-median, C - values 25 - $75 \%$, I...I - interquartile range (bottom and top quartile), o - extreme values 
Fig. 4 shows how the number of species (species diversity) changed in individual years. A substantial rise in the species diversity occurred in 1999, two years after the disastrous flood. In 2000-2001, the number of species dropped to approximately the same level, whilst 2002 and 2008 represent a slight decrease. Our own measurements in 2008 found 245 plant species in 58 relevés.

Combinations of frequency, fidelity and cover maximum value served for the creation of a synoptic table in JUICE 7.0. Diagnostic species are listed in descending order according to fidelity. Constant and dominant species are listed in descending order according to their frequency. Only a list of species is provided for biotopes. An appearance of a species in a reléve was only taken into account if its cover exceeded the set threshold value.

The following values were used for the analysis:

Threshold fidelity value for diagnostic species: 35 (40)

Threshold frequency value for constant species: 55 (55)

Threshold frequency value for dominant species with cover up to 25: 0 (100)

Table 2: The synoptic table of species in individual biotope types

\begin{tabular}{|c|c|c|c|c|}
\hline species & biotope 1 & biotope 2 & biotope 3 & biotope 4 \\
\hline \multirow[t]{5}{*}{ diagnostic } & Salix purpurea & Agrostis stolonifera & Arenaria serpyllifolia & Apera spica-venti \\
\hline & Myosoton aquaticum & Arctium lappa & Artemisia vulgaris & $\begin{array}{l}\text { Deschampsia } \\
\text { caespitosa }\end{array}$ \\
\hline & Persicaria hydropiper & Artiplex patula & Euphorbia cyparissias & Myosotis stricta \\
\hline & Urtica dioica & $\begin{array}{l}\text { Calamagrostis } \\
\text { epigejos }\end{array}$ & Silene vulgaris & \\
\hline & & Lactuca serriola & & \\
\hline \multirow[t]{2}{*}{ constant } & Phalaris arundinacea & Artemisia vulgaris & Tanacetum vulgare & $\begin{array}{l}\text { Arrhenatherum } \\
\text { elatius }\end{array}$ \\
\hline & & Phalaris arundinacea & & Tanacetum vulgare \\
\hline \multirow[t]{6}{*}{ dominant } & Salix fragilis & Salix viminalis & Salix alba & $\begin{array}{l}\text { Arrhenatherum } \\
\text { elatius }\end{array}$ \\
\hline & Salix purpurea & Salix fragilis & Echium vulgare & \\
\hline & Artemisia vulgaris & Echium vulgare & Festuca rubra & \\
\hline & Persicaria hydropiper & $\begin{array}{l}\text { Impatiens } \\
\text { glandulifera }\end{array}$ & Rubus caesius & \\
\hline & Phalaris arundinacea & Phalaris arundinacea & Solidago gigantea & \\
\hline & Urtica dioica & Urtica dioica & Urtica dioica & \\
\hline
\end{tabular}

The synoptic table (Table 2), with the diagnostic constant and dominant species, together with the synoptic table of species according to the highest fidelity value (Table 3 ) provide valuable data on species in the biotopes. For analysis, the biotopes in tables 2 and 3 have been classified into four groups.

Biotope 1 is diagnosed by hygrophilous species of plants and woody species, such as Salix purpurea and Myosoton aquaticum. Phalaris arundinacea is a constant species. Dominant species are mainly willows, e.g., Salix fragilis and Salix purpurea. Herbs present include Artemisia vulgaris and Persicaria hydropiper. Mainly wetland species are typical (fidelity over 30) of this biotope, e.g., Persicaria hydropiper, Myosoton aquaticum, and Persicaria lapathifolia. Floodplain species include Urtica dioica and Salix purpurea.

Biotope 2 is characterised by diagnostic species such as Agrostis stolonifera (meadow hygrophilous species) and Arctium lappa (ruderal species). Constant species are competitive strategists Artemisia vulgaris and Phalaris arundinacea. Dominant species are 
species of Salix (S. viminalis and S. fragilis). High-fidelity values are manifested by both meadow and ruderal species. Of meadow species, the following are abundant: Sanquisorba officinalis, Silene dioica and Populus nigra. Ruderal species include Arctium lappa and Lactuca serriola.

Table 3: Synoptic table with percentages and modified fidelity index phi coefficients (the numbers of biotopes are in the first line, and the numbers of relevés are below). The letter (S) by some Latin names of plants indicates the JUICE application nomenclature, which merged the same names of species (synonyms) into one valid name. The second column shows abbreviations of the ecological strategies of the species.

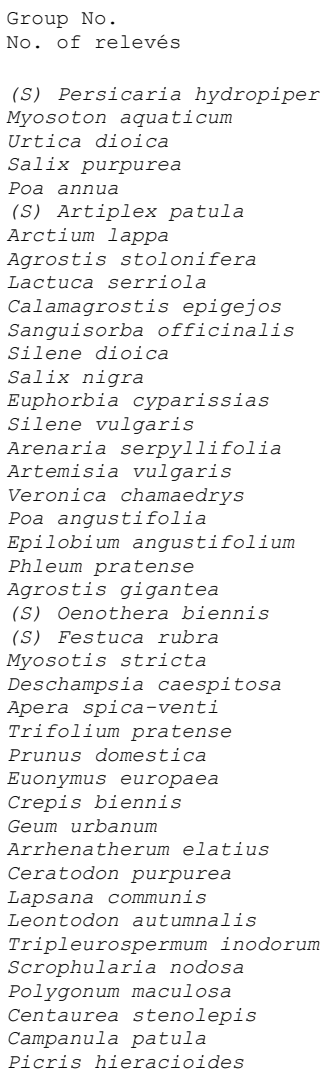

\begin{tabular}{|c|c|c|}
\hline & $\begin{array}{r}1 \\
19\end{array}$ & \\
\hline Cr & 47 & \\
\hline$C S$ & 58 & 43.6 \\
\hline C & 74 & 40.3 \\
\hline C & 26 & 40.2 \\
\hline$r$ & 32 & 33.5 \\
\hline$C r$ & . & \\
\hline C & 5 & --- \\
\hline $\operatorname{csr}$ & 26 & 3.0 \\
\hline$C r$ & 5 & --- \\
\hline C & 16 & --- \\
\hline C & . & --- \\
\hline C & . & $\cdots-$ \\
\hline C & . & --- \\
\hline $\operatorname{csr}$ & . & --- \\
\hline $\operatorname{cs} r$ & 11 & --- \\
\hline r & . & $\cdots-$ \\
\hline C & 53 & $\cdots$ \\
\hline $\operatorname{cs} r$ & . & -- \\
\hline C & . & $\cdots-$ \\
\hline C & . & --- \\
\hline C & . & -- \\
\hline$C$ & . & -- \\
\hline $\mathrm{Cr}$ & 11 & -- \\
\hline C & 5 & $\cdots$ \\
\hline$s r$ & . & $\cdots$ \\
\hline C & . & -- \\
\hline $\mathrm{Cr}$ & 5 & -- \\
\hline C & 5 & -- \\
\hline C & . & -- \\
\hline C & . & -- \\
\hline C & . & -- \\
\hline $\operatorname{cs} r$ & . & $\cdots$ \\
\hline C & . & --- \\
\hline Cr &. & --- \\
\hline $\operatorname{csr}$ & . & --- \\
\hline & 11 & --- \\
\hline$C S$ & 37 & 16.1 \\
\hline & 5 & --- \\
\hline C & . & $\cdots$ \\
\hline $\operatorname{cs} r$ & . & -- \\
\hline $\operatorname{cs} r$ & . & -- \\
\hline
\end{tabular}
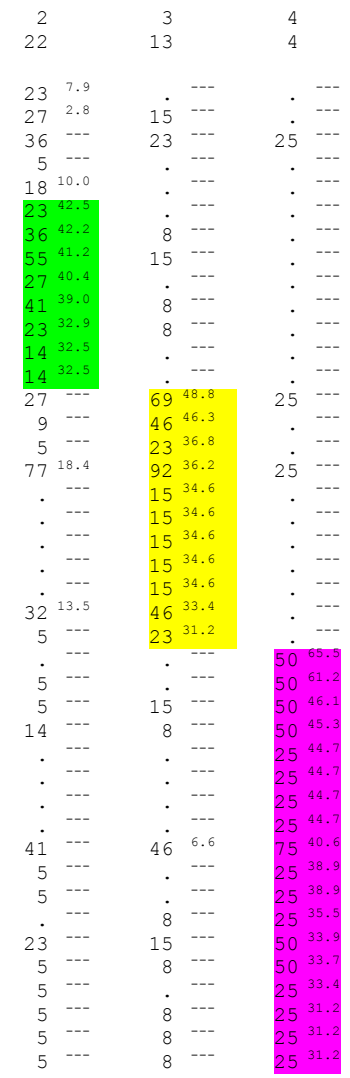

The main diagnostic species for biotope 3 include Arenaria serpyllifolia and Artemisia vulgaris. Tanacetum vulgar is a constant species, and dominant species include Salix alba and Echium vulgare. This biotope is characterised by an abundance of non-forest subxerophytes with an admixture of meadow mesophytes. Non-forest subxerophytes include Euphorbia cyparissias, Silene vulgaris, Arenaria serpyllifolia and Oenothera biennis. Meadow mesophytes, for example, are represented by Veronica chamaedrys and Phleum pratense.

There are mainly (fidelity over 25) species with ruderal tendencies in biotope 4, for example, Deschampsia caespitosa and Apera spica-venti (diagnostic species). According to 
Table 2, there are more meadow species, such as Trifolium pratense and Euonymus europaea. Diagnostic species include Apera spica-venti and Deschampsia caespitosa. Constant species include competitive strategists Arrhenatherum elatius and Tanacetum vulgare. The dominant species is Arrhenatherum elatius, representing meadow mesophytes.

Table 4: The Kruskal-Wallis test - Median values and standard deviations for the number of species, diversity indices, mean econumbers and strategies by particular biotope. The Kruskal-Wallis test was used to test the significance of the biotope effect on individual variables. Statistically significant values $(\mathrm{p}<0.05)$ are in bold.

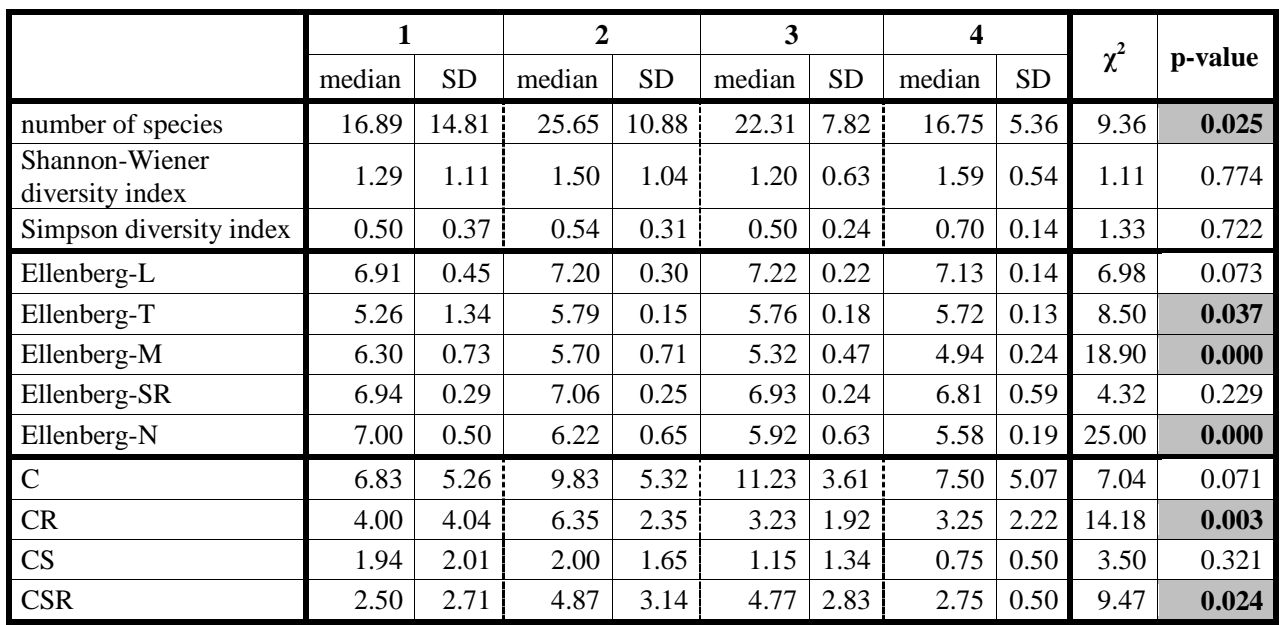

legend: SD - standard deviation, (Ellenberg) L - light, M - moisture, T - temperature, SR - soil reaction, $\mathrm{N}$ nitrogen, (strategies) $\mathrm{C}$ - competitor, $\mathrm{CR}$ - competitive ruderal strategy, CS stress tolerant competitor and CSR competitor stress tolerant ruderal strategy (transitional life strategy presumes three types of selection dependent on the environment)

The differences among individual types of biotopes (1-4) are summarised in Table 4 with the Kruskal-Wallis test, a non-parametric alternative to ANOVA test. Considering Table 4 as a whole, it is evident that in addition to the number of species, the biotope type has a statistically significant effect on Ellenberg's indication values of $T$ (temperature), $M$ (moisture) and $N$ (nitrogen). In contrast, it does not have a statistically significant effect on L (light) and SR (soil reaction). This may be caused by the favourable light conditions for the species that have adapted to this environment and are not considerably dependent on the soil reaction. The significant strategies are the competitive ruderal strategy $(C R)$ and the strategy of adaptation to the site where competition is decreased by the degree of stress intensity and biomass disturbance (CSR). The CR strategy category contains the species that are successful in productive sites where the biomass disturbance intensity is low (e.g., seasonal floods).

The $\mathrm{C}$ strategy is most represented in biotope 3 , characterized by optimum conditions (little stress and disturbance). In addition, this strategy is present in biotopes 2 and 4, where the disturbance is not as high as in biotope 1 .

The CR strategy is most represented in biotope 2; a lower proportion of this strategy is found in biotopes 1,3 , and 4 , where it is relatively equally important. 
The CS strategy is most represented in biotope 2 and less in biotope 1 . In these biotopes, there are species that can endure stress. The species in biotopes 3 and 4, located farther from the water current, do not face such great stress and disturbance.

The CSR strategy is most represented in biotopes 2 and 3. This transitional strategy is most common in these biotopes because it involves the transition between the surrounding river landscape and the landscape that contains fields and meadows.

The same results for these strategies are graphically presented in Figure 13.

Table 5: Spearman's correlation coefficients for the year of taking relevés and the examined variables (diversity indices, number of species, mean Ellenberg's indication values and species proportion by strategy) calculated separately for biotopes 1 to 3 .

\begin{tabular}{|l|l|l|l|l|l|l|}
\hline \multicolumn{7}{|l|}{ year of taking relevés } \\
\hline & \multicolumn{2}{|l|}{ biotope 1} & \multicolumn{2}{l|}{ biotope 2} & \multicolumn{2}{l|}{ biotope 3 } \\
\hline Shannon-Wiener index & -0.82 & $* * *$ & -0.52 & $*$ & -0.61 & $*$ \\
\hline Simpson index & -0.84 & $* * *$ & -0.50 & $*$ & -0.56 & $*$ \\
\hline number of herbs & -0.53 & $*$ & -0.40 & n.s. & -0.38 & n.s. \\
\hline EIH temperature & -0.14 & n.s. & -0.26 & n.s. & 0.26 & n.s. \\
\hline EIH light & 0.14 & n.s. & -0.05 & n.s. & 0.18 & n.s. \\
\hline EIH moisture & 0.25 & n.s. & 0.15 & n.s. & -0.16 & n.s. \\
\hline EIH pH & -0.54 & $*$ & -0.08 & n.s. & -0.18 & n.s. \\
\hline EIH nitrogen & 0.61 & $* *$ & 0.20 & $* *$ & -0.27 & n.s. \\
\hline C strategy $(\%)$ & 0.58 & $*$ & 0.16 & n.s. & 0.03 & n.s. \\
\hline CS strategy $(\%)$ & -0.04 & $* *$ & -0.10 & n.s. & -0.56 & $*$ \\
\hline CSR strategy (\%) & -0.63 & n.s. & -0.53 & n.s. & 0.07 & n.s. \\
\hline CR $(\%)$ & -0.22 & n.s. & 0.40 & n.s. & 0.09 & n.s. \\
\hline R $(\%)$ & -0.70 & $* *$ & -0.30 & n.s. & 0.36 & n.s. \\
\hline SR $(\%)$ & -0.43 & n.s. & -0.15 & n.s. & 0.51 & n.s. \\
\hline
\end{tabular}

Legend: n.s. - not significant, the significance level of the correlation coefficient is expressed by asterisks $(* \mathrm{p}=0.05 ; * * \mathrm{p}=0.01 ; * * * \mathrm{p}=0.001)$

Table 5 shows that the most significant dependencies between the year of taking relevés and analysed variables (e.g. Shanon-Wiener and Simpson indices, EIH nitrogen, CS and $R$ strategies) were found for biotope 1. It follows that the year of taking relevés has a significant effect on indices.

Fig. 5: Graph of Shannon-Wiener diversity index at all plots in separate biotopes

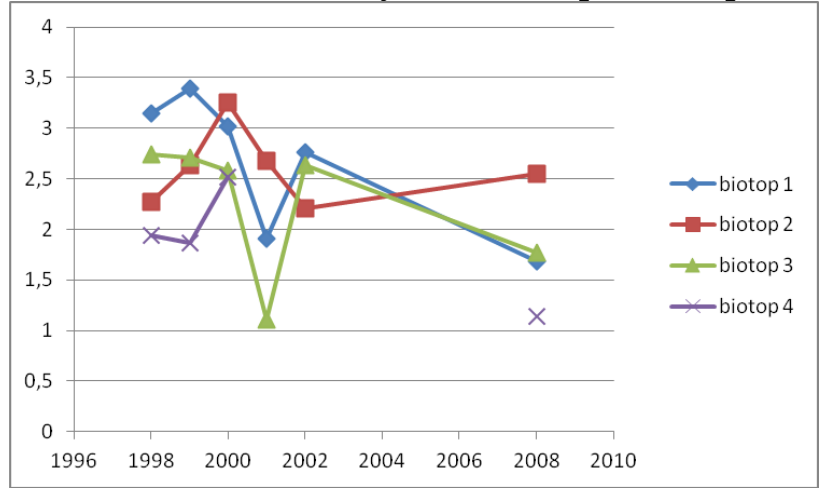


A significant trend appearing at all sites is the decreasing species diversity index in connection to the increasing time after the flood in 1997, as shown in Figure 5. From the flood in 1997 to 1998, the diversity increased considerably in biotopes 1 and 2. other biotopes manifested a slight decrease. The most apparent is the decrease in diversity in all biotopes after 2000. The trend of biotope 2 is different - it reached the highest diversity index in 2000, then kept dropping until 2002 and finally slightly increased in 2008.

The graph of proportions of ecological groups of species at site L in Fig. 6 shows that after the flood in 1997, species related to the bare bar of flysch sediments and ruderal species appeared (including segetal species). The proportion of floodplain forest species is lower than in the subsequent years. By gradual succession, in 1999-2000, floodplain and meadow mesophilous species became widespread. The proportion of invasive neophytes two years after the flood in 1997 was minimal. A more considerable expansion of neophytes started as late as in 2000. The year 2008 manifests the highest abundance of these species out of all the monitored years, mainly in biotopes 1 and 3. A marked increase in the proportion of woody species occurred two years after the flood, in 1999 (Fig. 9). Until 2008, the trend of the proportion of woody species remains constant. In contrast, the herb layer manifests a substantial expansion in comparison to 2000.

The graph in Fig. 7 shows that the succession at site $M$ was similar to that at site L. In the first two years after the disastrous flood, there was a higher occurrence of ruderal species. In 2000, a sharp rise in alluvial species began. In contrast to the previous site, invasive neophytes were most represented in 2001, whereas in 2008 their proportion dropped. This may have been caused by the flood of 2002, which was not as strong here as in Bohemia. However, in this region, considerable disturbance to the vegetation was caused at three locations on the above-mentioned gravel bars. In contrast to the gravel bar at site L, the species related to bare gravel bars appeared only exceptionally (only in 1999 and negligibly in the other years). Wetland species are represented quite abundantly, mainly in biotope 1 . In the third year after the flood, woody species played an important role; however, they are not present at such a degree in the following year. This phenomenon has not been any further specified by the author of the data (Klečka, 2004a). In 2008, woody species and herbs are abundant (Fig. 10).

The succession at site $\mathrm{R}$ proceeded in a slightly different way (Fig. 8). A year after the flood in 1997, there was a sharp increase in meadow mesophilous species and species related to bare gravel bars; however, in 2002 and 2008, there was a predominant proportion of floodplain forest and wetland species. Despite the poorer species variety, this site shows a fast succession and a rise in the number of woody species, mainly willows (see diagram, Fig. 12). A considerable rise in the number of woody species is illustrated in Fig. 11, showing the cover of woody species and herbs at the site. In comparison to 2000, the number of woody species in 2002 was halved. In comparison to 2002, the number of woody species in 2008 was more than doubled. The graph shows absolute values with cover; letter $\mathrm{D}$ denotes woody species, and letter B denotes herbs. 
Fig. 6: The percentages of ecological groups of species at site $L$

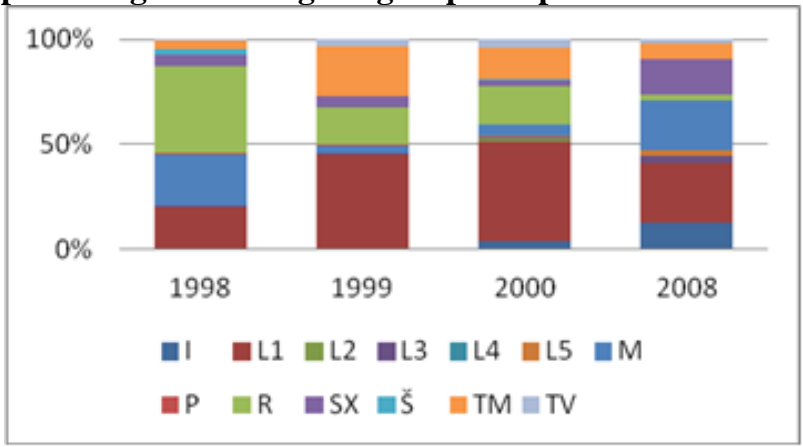

Fig. 7: The percentages of ecological groups of species at site $M$

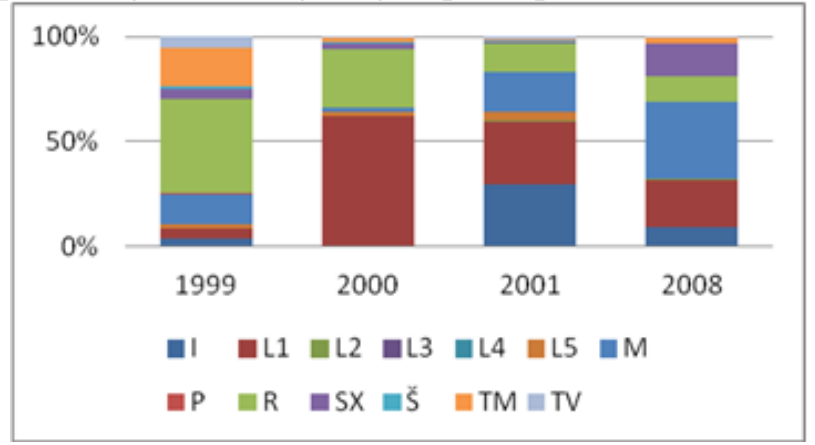

Fig. 8: The percentages of ecological groups of species at site $R$

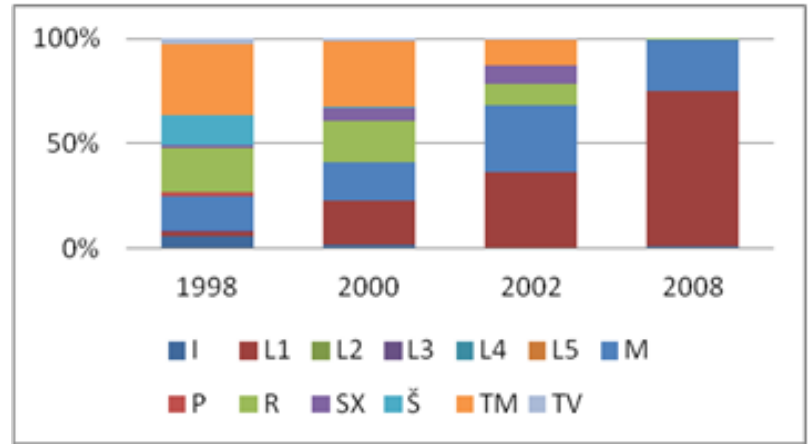

Legend

$\breve{\mathrm{S}}$ - species related to bare gravel bars

TM - meadow mesophilous

$\mathrm{L} 1=$ floodplain forests

$\mathrm{L} 2$ = grove forests

L3 = medium-altitude forests

L4 = mountain forests (montane forests and

submontane forests)

L5 = small felling areas

SX - non-forest subxero-thermophilous

TV - meadow hygrophilous

TA - meadow mountainous

$\mathrm{M}$ - wetland

$\mathrm{P}$ - farm plants and garden (decorative) plants

$\mathrm{R}$ - ruderals (including segetals)

I - invasive neophytes (proportion of ruderals) 
Fig. 9: The percent cover of woody species and herbs

on site $L$

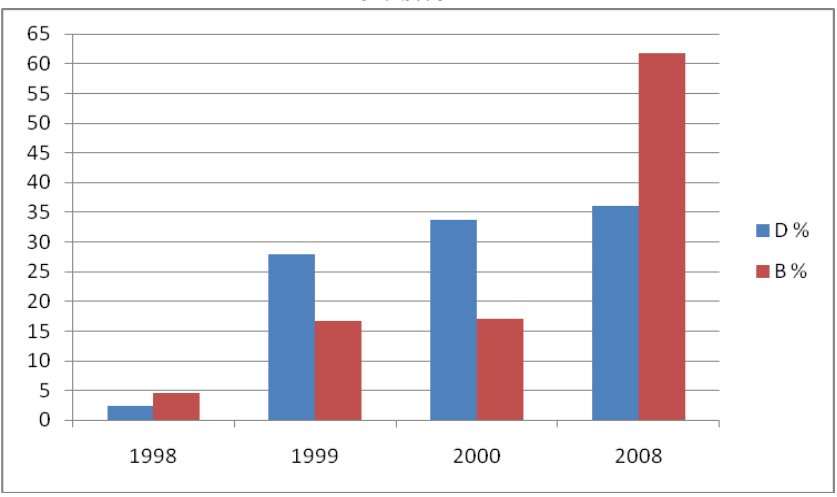

Legend: D - woody species, B - herbs

Fig. 10: The percent cover of woody species and herbs

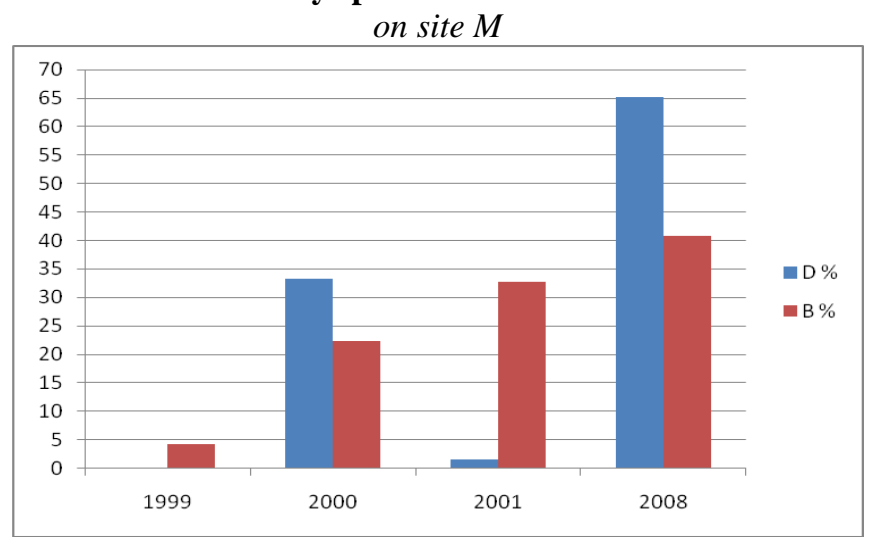

Legend: D - woody species, B - herbs

Fig. 11: The percent cover of woody species and herbs

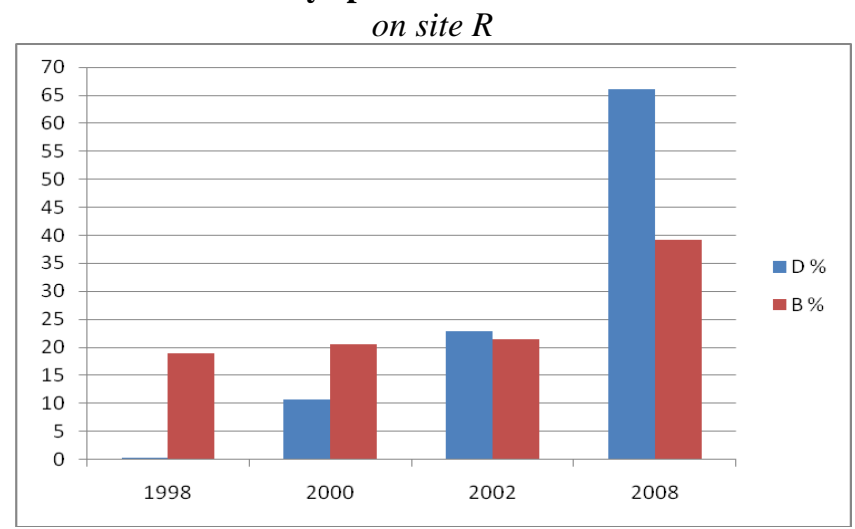

Legend: D - woody species, B - herbs 
Fig. 12: A diagram of the vegetation development in biotopes of the Rybář gravel bar (drawn upstream of the Bečva River)
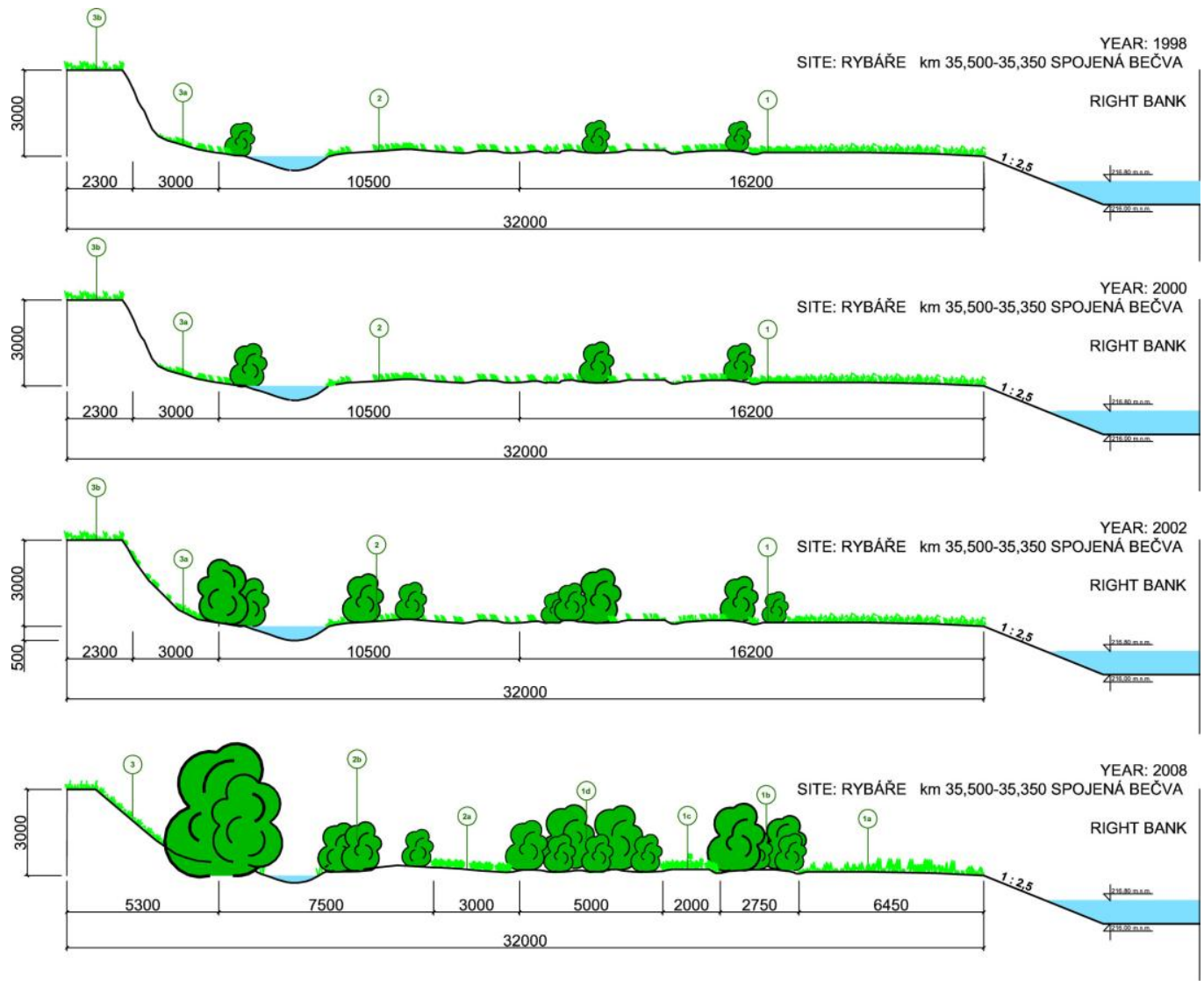

Fig. 13: The proportion of population strategies in individual types of biotopes according to Slavíková (1986)
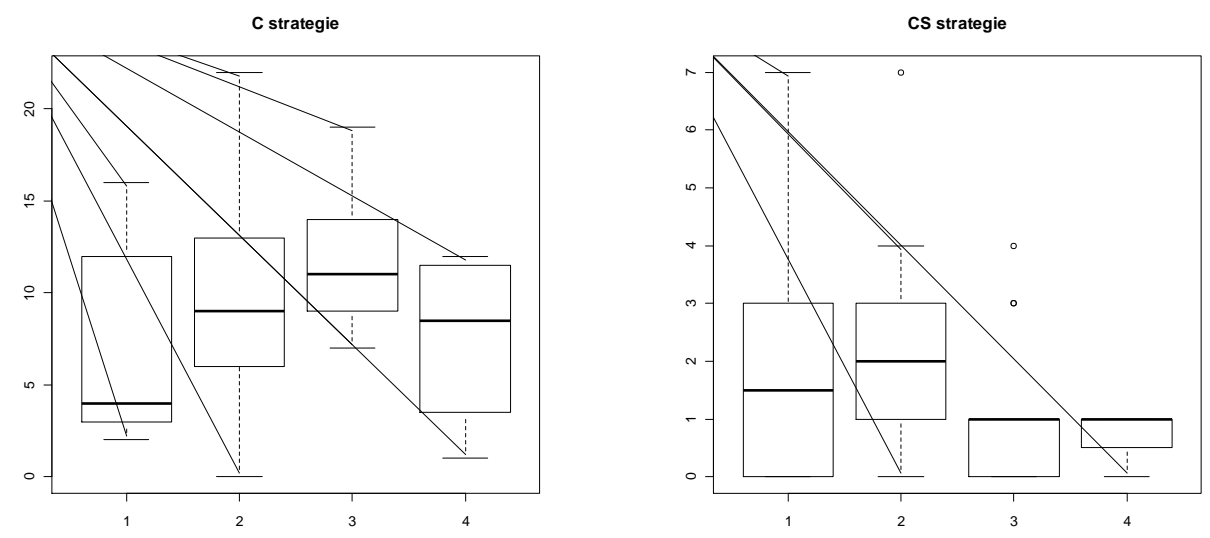

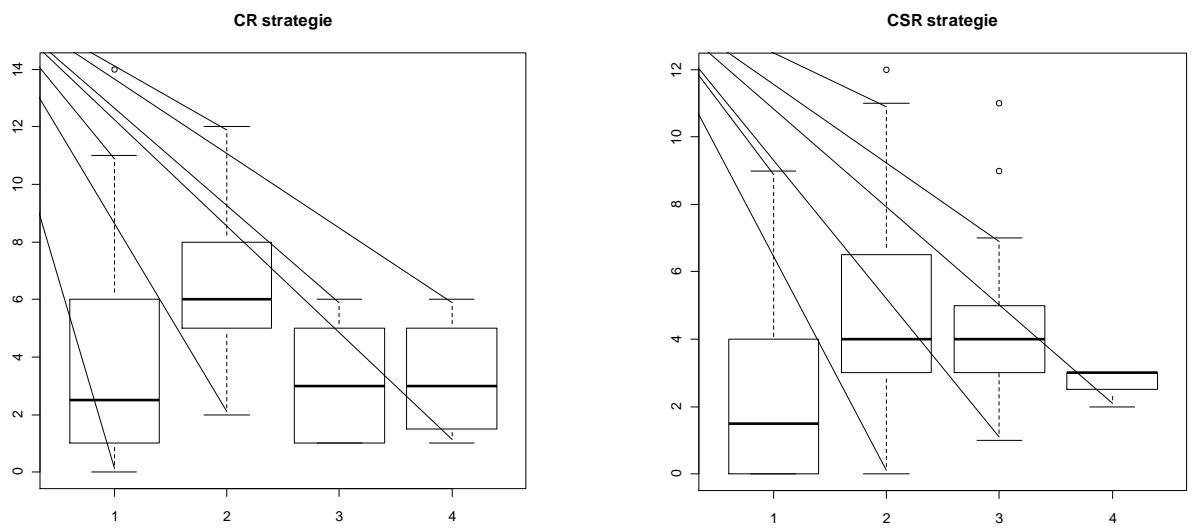

Legend:

C-competitor

$\mathrm{CS}$ - stress-tolerant competitor

$\mathrm{CR}$ - competitive ruderal strategy

CSR - transitional life strategy presuming three types of selection dependent on the environment: Ccompetitor, S-stress-tolerator and R-ruderal. R, SR and S were represented only to a negligible degree; therefore, they are not displayed in graphs.

\section{DISCUSSION}

The issue of the development of vegetation cover at the selected sites has been addressed by Lacina $(2003,2007)$ since 1987 . This work is focused on the profile at Osek nad Bečvou. The collected phytocoenological relevés were evaluated every 5 years. Every other evaluation (every 10 years) devoted special attention to ecotones. Early stages of floodplain forest succession in wide river beds based on the example of the Bečva have been described by Klečka (2004b). Both authors agree on their description of the destructive impact of the June flood in 1997 on vegetation; this is because only the species with well-developed vegetative organs survived, such as Urtica dioica, among invasive species, Reynoutria japonica, Solidago gigantea and Solidago canadensis, and Helianthus tuberosus. Contrary to expectations, invasive neophytes appeared only scattered in the newly formed flood channel at early succession stages. However, the flooding of the area did not have a permanently detrimental effect on most species, and the structure of the herb layer in the subsequent growing season corresponded to the condition before the flood. High percentage cover was reached the fastest in the flood channel sections with fine fill, while in the sections of gravel bars devoid of fine fill the vegetative cover remained low.

Faster regeneration of communities was observed in areas where fine sand and gravel sediments constituted the largest fractions of the soil. This trend was also demonstrated by a number of other studies (Klečka, 2004b; Lacina 1999, 2000; Vatolíková 2004; Grohmanová 2006a, 2006b, 2007 and Šaňková 2009). In addition, Gilver and Willby (2006) include floods, altitude, age and distance from the water surface in the list of variable characteristics affecting the composition of vegetation in gravel bars. Floods affect the vegetation composition, and the altitude affects the structure and thickness of the sediment - with increased elevation, more stable conditions are encountered, and coarse sediments prevail. At lower altitudes, disturbances are more frequent, and fine sediments, which are usually more fertile, settle. Another variable is the age, which influences the 
structure and composition of the community. Finally, the distance from the water current plays an important role in the moisture regime and the creation of stagnant lakes and lagoons in typical communities. Moreover, the morphology of the site is important for the creation of a varied mosaic of plant communities.

At initial stages of the succession after the disastrous flood in 1997 - in the first three years - the essential factors in the process of community development were the availability of moisture, light demands and demands for mineral nitrogen (Klečka, 2004a). Klečka states that, at the initial stages, the gravel bars were fully sunlit, and later, with the development of vegetation, the light conditions at the sites became more differentiated. In this way, sites with closed-canopy willow stands were formed in places where shadetolerant species also became established. Concerning the demands for mineral nitrogen, there were species characteristic of nitrogenous soils. During 1999-2001, the cover increased from approximately $3 \%$ to $26 \%$. With regard to soil reaction, values of $\mathrm{pH}$ depended on the river water.

Results show that the main requirements of the community also included moisture, light and mineral nutrients. The significant factors explaining site diversity were the biotope, site and year of recording. The percentage cover of species grouped by strategy type, ecological group, and other factors were analysed. The development of the vegetation cover (oecesis and primary succession) in the newly formed flood channel (on gravel bars and partially on bare flysch subgrade) was explored.The results of the analyses and field mapping show that succession proceeded most rapidly at site $\mathrm{R}$, although this site has the lowest species diversity among the three sites.

At site $M$ below the Choryně village, the appearance of herbs and woody species was gradual, as proved by Klečka (2004a). The profile of research presented in this paper corresponds to the B2 profile. Site L has also developed well since the flood in 1997: The persisting plant species at this site include closed-canopy willows, alternating with bands of lower herbs among rocks and gravel sediments with very fine fill.

\section{Invasive neophytes}

Šaňková (2009) ascertained a rapid increase in neophytes, such as Reynoutria japonica, Solidago canadensis and Impatiens glandulifera, on the Opava River in 2005-2007. In contrast to the Bečva River, the author also found a rapid increase in Lupinus polyphyllus.

After the flood of 1997, Impatiens glandulifera and Solidago sp. became widespread on the Orlice River (Kovár et al. 2002). The rapid spread of invasive neophytes, especially Reynoutria japonica and Solidago gigantea, at newly established sites in the Bečva River is also reported by Klečka (2004a). This author also describes Aster novi-belgii, Helianthus tuberosus, Impatiens glandulifera and Lupinus polyphyllus as common but not abundant species. In the last decade, it was found that invasive neophytes appeared in riparian stands in continuous bands (Grohmanová, 2006a). This observation is also confirmed by Chuman et al. (2008). Maděra and Ǩepka (2010) report that, out of all recorded higher species in floodplain forests of the lower Morava River, $25 \%$ are considered opportunistic, of which 48 species are considered invasive (Pyšek et al., 2002). It follows that opportunistic or invasive species currently form a substantial component of the vegetation of floodplains, not only in the Czech Republic but also in other parts of the world (De Ferrari and Naiman, 1994; Planty-Tabacchi et al., 1996; Pyle, 1995; Stohlgren et al., 1998).

The spread of invasive neophytes in a river floodplain represents a serious ecological problem. An expansion of these species after floods, but also after stream regulation, as argued by Kopecký (1969), leads to a decrease in the populations of local species. For example, Reynoutria, a perennial plant - which is invasive and widespread in many 
European regions - causes damage in destabilising the banks of waterlines or slopes of traffic lines. Therefore, a system of early detection is needed that will allow for the classification of neophytes, and the launching of early control actions if necessary (Bohren, 2009).

The colonisation and succession of bare gravel bars and their incorporation in the floodplain is critical for the maintenance of high landscape biodiversity (POFF and WARD, 1990). Floods, in any of their forms, are important for the maintenance of the multitude of landforms and processes characteristic of natural gravel bars and islands, which are important in maintaining plant diversity (Gilvear, Willby, 2006).

\section{CONCLUSION}

Field research connected with the mapping of biotopes on selected portions of the Spojená Bečva River over ten years has brought significant scientific knowledge regarding the dynamics of the successional development of communities surrounding a river bed. It has also provided a valuable source of information for nature conservation.

The analysis of the three research sites presented in this paper demonstrates that each of these sites is at a different stage of succession. What differs between the sites is not only the proportion of herbaceous species but also the differentiation of woody species into different successional stages of each biotope.

From the perspective of a successional stage, the vegetation on the gravel bar in Rybáre near Drahotuše (site $R$ ) is the most developed. The gravel bar is nearly straight, i.e., parallel with the stream, with a rocky bank further from the current below finely sedimented gravel with a high content of nitrogen. When the water is high on this side of the river, the rocky bank reduces erosion. In the time series, there is a typical and considerable expansion of the community, which currently forms closed-canopy stands comprising (generally) the most developed communities with prevailing willows, especially Salix purpurea and Salix fragilis. A lower number of species is mainly influenced by the shade of the partially closed-canopy woody layer.

Among communities of woody species, plants linked to higher moisture levels appear in slight terrain depressions, e.g., Phalaris arundinacea, Urtica dioica and Mentha longifolia. The number of species present is lower in comparison with the other two sites, which may be caused by a reciprocal influence of the vegetation on site conditions (the most abundant species colonise new places, although there are unfavourable site conditions, and species competition is at work). Thus, the process of homogenisation occurs, as Klečka (2004 b) also concluded.

The vegetation in gravel bars in Choryně "Výústění potoka Mřenky" (site M) is less advanced in succession. This gravel bar is the most disturbed during floods and elevated water levels. In addition, the effect of the Mřenka Stream, which flows into the river across the gravel bar, is of a certain significance. Another significant factor of succession of this large gravel bar is the influence of a slightly sedimented area further from the Bečva River, where more xerophilous species tolerant of direct sunlight grow, e.g., Echium vulgare. This site has higher species richness than the previous site. There is also an indication of spatial differentiation of vegetation adapted to the different site conditions, which are substantial along the transect. As previously described, more xerophilous vegetation appears in the areas exposed to direct sunlight towards floodplain forests, whereas in the direction of the stream, there are relatively well-established species of shrub and willow trees together with hygrophilous and flood-tolerant vegetation. 
Species richness is the highest at the "Pod Břehy" site (site L), which, in terms of successional advancement, is comparable to that of site $\mathrm{M}$. In contrast to site $\mathrm{M}$, this gravel bar is not as disturbed (no stream flows here), and the narrow band exposed to the direct sunlight changes into a biotope sloping towards a hillside. Similarly to the previous site, the tree layer is closed and, viewed from above, forms nearly closed stands. Species richness is explained by the variability of soils and substrates. The variability of these biotopes is caused by differing conditions and associated species. The riparian zone is mainly populated by Phalaris arundinacea together with Impatiens glandulifera. The woody layer consists of willows Salix alba, S. fragilis, and S. purpurea together with a mixture of birch Betula pendula and poplar Populus tremula, among others.

We can conclude, based on field mapping, that the appearance of invasive neophytes transitioned from negligible occurrence (shortly after the flood of 1997) to an expansive increase in the last five years. Elevated water levels (e.g. floods) flush seeds and plants downstream. As they spread to new places higher in the floodplain, they take root and flourish. This was exhibited in the study territory after the flood in 1997.

By maintaining sections of the original reformed bed with a mosaic of biotopes, we support species diversity and the variability of the fluvial landscape, with its naturally high ecological stability. The restoration of fluvial processes will sustain the biodiversity of the fluvial landscape and allow further research regarding riparian succession. Results of such research will then serve as a source of information for protection at regional, supra-regional or international levels.

\section{ACKNOWLEDGEMENTS}

This study is a product of the Research Project IGA 2/2008 "Succession of alluvial biotopes after the flood in 1997'. Furthermore, the article was published thanks to a support from the Internal Grant Agency of Faculty of Forestry and Wood Technology Mendel University in Brno (project reg. No. 12/2010) and faculty research program reg. No. MSM 215648902). I would like to thank Ing. Jan Šebesta for helping me process statistical data. My thanks belong to Dr. Jan Lacina and Mgr. Jan Klečka for providing their data. I also thank my supervisor, Dr. Petr Maděra, for his advice and comments on this paper.

\section{REFERENCES}

Ambros, Z. (2003). Praktikum geobiocenologie. Mendelova zemědělská a lesnická univerzita v Brně, Brno, p. 97.

Ambros, Z., Štykar, J. (1999). Geobiocenologie I. Mendelova zemědělská a lesnická univerzita v Brně, Brno, p. 63.

Bayley, P. B. (1995). Understanding large river-floodplain ecosystems. Bioscience 45 (3), 153-158.

Buček, A., Lacina, J. (1994). Význam říčních ostrovů pro poznání sukcese v nivní krajině na př́kladu nivy řeky Opavy. In.: E. Križová, Ujházy, K. Sekundárna sukcesia II. (15-22). Zborník referátov zo seminára, Zvolen:

Buček, A., Lacina, J. (1999). Geobiocenologie II. MZLU Brno.

Buček, A., Florová, K., Králová, H., Kundrata, M. \& Machů, R. (1998). Analýza povodňových událostí v ekologických souvislostech. Unie pro řeku Moravu, Brno. 
Buček, A. (1998). Analýza povodňových událostí v ekologických souvislostech, Unie pro řeku Moravu, Brno.

Buček, A. (2010). Nivní fenomén a vodohospodářské paradigma. In L. Drobilová, Venkovská krajina, 1. vyd. (p. 15-20). Zámek 1, 28163 Kostelec nad Černými lesy: Lesnická práce s.r.o.

Bohren, C. (2009). Neophytes and other environmental weeds disturb miss agriculture: Ambrosia, Solidago and Reynoutria, XIII. Collonque international sur la biologie des mauvaises herbes dijon 8. - 10. Septembre 2009.

Chuman, T. Lipský, Z. \& Matějíček, T. (2008). Stav poznání o vlivu extrémních záplav na vegetaci údolních niv. In: Langhamer (Ed.) a kol.: Změny v krajině a povodňové riziko. (p. 226-232). Univerzita Karlova v Praze, Přírodovědecká fakulta, katedra fyzické geografie a geoekologie, Praha

Chytrý, M., Kučera, T. \& Kočí, M. (2001). Katalog biotopů České republiky. AOPAK ČR Praha, p. 304

Chytrý, M., Kučera, T., Kočí, M., Grulich, V. \& Lustyk, P. (2010). Katalog biotopů České republiky. 2. vydání. Agentura ochrany př́rody a krajiny ČR, Praha. 448 p.

Culek, M. (1996). Biogeografické členěni České republiky. Praha: ENIGMA, 1996. p. 347.

Czudek, T. (1997). Reliéf Moravy a Slezska v kvartéru. Tišnov, Sursum, p. 213.

De Ferrari, C. M., Naiman, R. J. (1994). A multi-scale assessment of the occurrence of exotic plants on the Olympic Peninsula, Washington. J. Veg. Sci. 1994, 5: 247-258.

Demek, J.(1987). Zeměpisný lexikon ČSR. Hory a nižiny. Brno: Academia, p. 584.

Dufręne, M., Legendre, P. (1997). Species assemblages and indicator species: the need for a flexible asymmetrical approach. In Ecol. Monogr. 67: 345-366.

Ellenberg, H. (1996). Vegetation Mitteleuropas mit den Alpen. 5. Stuttgart: Ulmer, p. 1096.

Gilvear, D., Willby, N. (2006). Channel dynamics and geomorphic variability as controls on gravel bar vegetation; river Tummel, Scotland, Wiley InterScience 22:457-474.

Grime, J. P. (1979). Plant Strategies and Vegetation Processes. Wiley.

Grohmanová, L. (2008). Sukcesní vývoj nivních společenstev po povodni v roce 1997, Závěrečná zpráva - IGA č. 2/2008.

Grohmanová, L. (2006a). Návrh péče o biotopy povodňového koryta a nivy Bečvy pod Valašským Meziřič́m (diplomová práce), LDF MZLU Brno, p. 65 + apendix.

Grohmanová, L. (2006b). Fluviální sukcesní série v povodí nivy Bečvy, In: Geobiocenologie a její aplikace, (p. 163-173). MZLU Brno, ISBN: 978-80-7375-130-2.

Grohmanová, L. (2007). Hodnocení změn nivních geobiocenóz řeky Bečvy následkem povodně, 24. výroční konference Fyzickogeografické sekce České geografické společnosti, Brno, p. 134-139.

Hennekens, S. M., Schamineé, J., H., J. (2001). TURBOVEG, a comprehensive data base management system for vegetation data. In Journal of Vegetation Science 12: 589-591.

Hill, M. O. (1973). Diversity and evenness: A unifying notation and its consequences, Ecology, Ecological Society of America, Vol. 54, No. 2.

Klečka, J. (2004a). Změny v geobiocenózách řiční nivy následkem povodně na př́kladu Spojené Bečvy (disertační práce), LDF MZLU Brno, p. 65 + appendix. 
Klečka, J. (2004b). Early stadiums of floodplain forest succession in wide river beds upon an example of Bečva, Journal of forest science, (7):338-352.

Kopecký, K. (1969). Změny druhového složení některých fytocenos v inundaci dolního toku Orlice po záplavách v roce 1965, Preslia, 4, p. 284-296.

Kovár̆, P. (2002). Ekologický význam vegetačni sukcese v řiční nivě po extrémních záplavách. Souhrn dosažených výsledků, Projekt GAUK 126/2000/B/BIO, Př́rodovědecká fakulta Univerzity Karlovy, Praha.

Lacina, J., Mackovčin, P., Hrádek, M., Kirchner, K. \& Řepka R. (1998). Sledování sukcese vegetace a vývoje řičního koryta ve vybraných profilech Spojené Bečvy mezi Osekem nad Bečvou a Valašským Meziřičím (Výzkumná zpráva) - Ústav geoniky AVČR a AOPK ČR Brno, p. 61.

Lacina, J. (1999). Výzkum změn biocenóz a vývoje říčního koryta ve vybraných profilech Bečvy po povodni 1997 (preliminary communication). In: Povodně, krajina a lidé v povodí řeky Moravy I. dil, (p. 46 - 52.). REGOGRAPH pro Ústav Geoniky AVČR, Brno

Lacina, J. (2003). Sukcese v povodňových korytech moravských řek na př́kladu Bečvy a Desné. In: Řični krajina, (p. 130-139), PřF UP Olomouc

Lacina, J. (2007). Desetiletý vývoj vegetačního krytu povodňového koryta Bečvy se zvláštním zřetelem na ekotony. In: Říční krajina 5, (p. 145-151), Univerzita Palackého Olomouc, ISBN 978-80-224-1890-2.

Maděra, P., Řepka, R. (2010). Evaluation of vascular plants biodiversity in floodplain forests of the alluvium of the Morava River. In.: I. Machar, (Ed.): Biodiversity and target management of floodplain forests in the Morava River basin. (pp. 54-80) Palacky Univesity in Olomouc

Maděra, P., Šebesta, J., ̌̌epka, R. \& Klimánek, M. (2011). Vascular plants distribution as a tool for adaptive forest management of floodplain forests in the Dyje river basin. Journal of Landscape Ecology, 4, 2: 18-34.

Maděra, P., Vukelić, J., Buček, A. \& Baričević, D. (2008). Floodplain Forests Plant Communities. In. E. Klimo, H. Hager, S. Matić, I. Anić, J. Kulhavý (Eds): Floodplain Forests of the temperate zone of Europe. (pp. 102-159). Lesnická práce, Kostelec nad Černými lesy, ISBN 978-80-87154-16-8.

Malanson, G. P. (1993). Riparian Landscapes. Cambridge University Press, New York.

Planty-Tabacchi, A., Tabacchi, E., Naiman, R. J., De Ferrari, C. M., \& Decamps, H.: Invasibility of species-rich communities in riparian zones. Conservation Biol., 1996, 10: 598-607.

Poff, N., Ward, J. (1990). Physical habitat template of lotic systems: recovery in the context of historical pattern of spatiotemporal heterogeneity. Environmental Management 14: 629645.

Pyle, L. L. (1995). Effects of disturbance on herbaceous exotic plant species on the floodplain of the Potomac River. Amer. Midl. Naturalist,134: 244-253.

Slavíková, J. (1986). Ekologie rostlin, SPN Praha.

Steiger, J., Tabacchi, E., Dufour, S., Corenblit, D. \& Peiry, J. L. (2005). Hydrogeomorphic processes affecting riparian habitat within alluvial channel-floodplain river systems: a review for the temperate zone. River Res. Appl. 21, 719-737.

Stohlgren, T. J., Bull, K. A., Otsuki, Y., Villa, C. A. \& Lee, M. (1998). Riparian zones are havens for exotic plant species in the central grasslands. Pl. Ecol., 138: 113-125. 
Šaňková, B. (2009). Vegetace údolních niv ve vztahu $k$ fluviálním procesům a tvarům vybraných řek Hrubého a Nizkého Jeseniku. Disertační práce, Brno, pp. 114

Tichý, L. (2002). Juice, software for vegetation classification. Journal of Vegetation Science 13: 451-453.

Vatolíková, Z. (2004). Biotopy povodňového koryta Bečvy (diplomová práce), LDF MZLU Brno, p. $61+$ appendix.

Ward, J., V., Tockner, K., Uehlinger, U. \& Malard, F. (2001). Understanding natural patterns and processes in river corridors as the basis for effective river restoration. Regulated Rivers: Research \& Management 17, 311-323.

Ward, J.,V., Malard, F. \& Tockner, K. (2002). Landscape ecology: a framework for integrating pattern and process in river corridors. Landscape Ecology 17 (suppl. 1), 35-45.

Wenger, E.L., Zinke, A. \& Gutzweiler, K.A. (1990). Present situation of the European floodplain forests. Forest Ecology and Management, 33-34, p. 5-12.

Zlatník, A. (1970). Lesnická botanika speciální. SZN Praha, pp. 667

Zlatník, A. (1976). Přehled skupin typů geobiocénů pưvodně lesnich a křovinných. Zprávy Geografického ústavu ČSAV, č. 13., Brno, č. 3-4, p. 55-64 + 1 tab. in appendix

\section{Internet sources:}

cykloserver.cz

maps.google.cz

http://uprm.sweb.cz/krajina_a.html 